\title{
Diz çevresi osteotomilerinin kıkırdak basıncı ve rejenerasyonu üzerine etkileri
}

\section{Effects of osteotomies around the knee on cartilage pressure and regeneration}

\author{
Alper Kaya \\ Acıbadem Mehmet Ali Aydınlar Üniversitesi, Tıp Fakültesi, Ortopedi ve Travmatoloji Anabilim Dalı, İstanbul
}

\begin{abstract}
Dizilim bozukluğuna bağlı eklemdeki asimetrik yüklenmeler karşı kompartmanda artmış yüklere neden olarak kıkırdakta ilerleyen aşınmaya yol açar. Bunun sonucunda genç-orta yaş grubu hastalarda ağrı ve günlük aktivitelerde bozukluklar görülmektedir. Osteotomiler ekstremitedeki deformiteyi mekanik ekseni kısmen karşı kompartmana taşıyarak etkilenen kıkırdaktaki temas basıncını azaltır. Bu durum eklem kıkırdağında daha fazla aşınmayı engelleyen yeterli bir mekanik ortam oluşturur ve eklem artroplastisi gerekliliğini geciktirir veya bazı hastalarda gerekliliği ortadan kaldırabilir. Güçlü tespit materyalleriyle erken yük verme, erken hareket açıklı̆ının kazanılması, iyileşmeye ve normal aktivitelere daha çabuk dönülmesine katkıda bulunur ve kıkırdak yenilenmesini olumlu yönde etkiler. Osteotomilerle kıkırdakta rejenerasyon olup olmadığı tartışmalı olmakla birlikte bu konuda yapılmış bazı çalışmalar kıkırdak basıncındaki azalmayla birlikte rejenerasyonun tetiklendiğini ortaya koymaktadır. Bu derlemede tek başına osteotomi ile veya beraberinde abrazyon, subkondral drilleme veya mikrokırık, otolog kondrosit implantasyonu, mozaikplasti, trombositten zengin plazma ve kök hücre tedavileri gibi kıkırdak restorasyonunu amaçlayan işlemler ile birlikte yapıldığında kıkırdakta görülen değişiklikler klinik, radyolojik, ikinci bakış artroskopisi ve histolojik değerlendirmelerle ortaya konan çalışmalar ışığında özetlenmiştir. $\mathrm{Bu}$ çalışmalara göre osteotomi tek başına veya biyolojikrejeneratif diğer işlemlerle birlikte yapıldığında farklı oranlarda kıkırdakta iyileşme görülebilmektedir.
\end{abstract}

Anahtar sözcülkler: dizilim; osteotomi; kıkırdak basıncı; kıkırdak rejenerasyonu

\begin{abstract}
Asymmetric joint load distribution in the knee due to malalignment can cause increased loads on the opposite compartment and induce progressive cartilage degeneration, and the results are pain and dysfunction of daily activities in young-middle aged patients. Osteotomies correct the limb deformity by shifting the mechanical axis partially to the opposite side and decreasing the contact pressure on the affected cartilage. This can provide the adequate mechanical environment for preventing further degeneration of the articular cartilage and they may delay or in some cases prevent the need for patients to undergo knee arthroplasty procedures. Early weight bearing is possible with strong plate-screw constructions, gaining early movement clearance contributes to recovery and a quicker return to normal activities, and early range of motion exercises positively affects cartilage regeneration. Whether regeneration of cartilage with osteotomies is a controversial issue, some studies have indicated that regeneration is promoted with decreased loading in cartilage. In this review, the changes seen in the cartilage after osteotomy with or without the cartilage repair techniques like abrasion, subchondral drilling, microfracture, autologous chondrocyte implantation, mosaicplasty, platelet-rich plasma and stem cell therapies are summarised with the studies considering clinical, radiological, second look arthroscopy and histological evaluations. According to these studies, when osteotomy is performed alone or with additional cartilage regenerative procedures, the degenerated cartilage could be covered partially or totally by newly regenerated cartilage.
\end{abstract}

Key words: alignment; osteotomy; cartilage pressure; cartilage regeneration
D iz eklemindeki dizilim bozuklukları, yük ekseninin değişmesi ile eklemin belli bir bölgesinde basınç artışına ve dolayısıyla bozulan biyomekanik ile kıkırdak kaybına neden olmaktadır. Özellikle genç-orta yaşlı ve aktivitesi yüksek olan hastalarda deformite nedeniyle gelişen artrozun tedavisi zordur. Bu hastalarda konservatif yöntemler her zaman yeterli olmamakta, artroplasti seçeneği ise daha ileri yaşta ve aktivitesi daha sınırlı hastalarda tercih edilmektedir. Eklemi koruyucu işlemlerden biri sayılan osteotomi bu hastalarda daha uygun bir tedavi seçeneğidir. ${ }^{[1]}$ Diz çevresindeki deformitenin osteotomi ile düzeltilmesinin temel amacı günlük aktivitelerle ekleme binen yük dağılımının dengelenmesi ve hastada işlev kaybına da

- İletişim adresi: Prof. Dr. Alper Kaya, Acıbadem Altunizade Hastanesi, Ortopedi ve Travmatoloji Kliniği, Tophanelioğlu Caddesi, Yurtcan Sokak, No: 1, Üsküdar, İstanbul Tel: 0532 - 6547734 e-posta: alperkaya@yahoo.com

- Geliș tarihi: 20 Ocak $2020 \quad$ Kabul tarihi: 1 Mart 2020 
yol açabilen ağrının azaltılması veya ortadan kaldırılmasıdır. Dizilimin düzeltilmesinin anormal yüklenme olan kompartmandaki basıncı azaltarak hasarlı eklem kıkırdağının iyileşmesini de uyarabileceği düşünülmektedir. $[2,3]$

Diz ekleminde var olan kıkırdak sorununu düzeltmeye yönelik işlemler için dizilimin ve stabilitenin normal olması beklenir. Yani kıkırdak yenileme için yapılacak işlemlerde eğer alt ekstremite dizilimi normal değil ise dizilim düzeltici osteotomi ön şartlardan sayılır. Böylece yük dağılım dengesi sağlanarak yapılacak onarım işleminin uzun dönem sonuçlarının iyi olması hedeflenir.

Kıkırdak yenileme işlemleri eklenmeden yapılan proksimal tibial osteotomilerin sonuçlarının değerlendirildiği geniş bir derlemede, klinik sonuçların kıkırdak hasarının derecesi, yaş, patellofemoral eklemin duru$\mathrm{mu}$, ameliyat öncesi eklem hareket açıklığı, geçirilmiş cerrahiler, dizin stabilitesi ve bağ laksitesi gibi etkenlere bağlı olarak değiştiği vurgulanmıştır. ${ }^{[4]}$ Özellikle genç, aktif, eklem hareket açıklığı geniş, bağ laksitesi olmayan izole medial osteoartritli hastalarda medial açık kama osteotomisi iyi sonuç veren ve komplikasyonu daha az bir cerrahi yöntemdir. ${ }^{[4-6]}$

Tek kompartman artrozu olan hastalarda dizilimi düzelten osteotomi tek başına yapılabileceği gibi, abrazyon, subkondral drilleme veya mikrokırık, otolog kondrosit implantasyonu, mozaikplasti, trombositten zengin plazma ve kök hücre tedavileri gibi kıkırdak restorasyonunu amaçlayan işlemler birlikte de yapılabilir. Diğer taraftan bakıldığında da, kıkırdak yenileyici bir işlem yapılması planlanan hastalarda eğer dizilim bozukluğu varsa düzeltici osteotomi de eklenmelidir. Bu bölümde tek başına veya eşlik eden kıkırdak yenileme işlem ve cerrahileri ile birlikte dizilim düzeltici osteotominin kıkırdak dokusunun yenilenmesi üzerine etkilerinin değerlendirildiği çalışmalar özetlenmiş̧tir. Radyolojik ve klinik değerlendirmelere dayalı kısa, orta ve uzun dönem çok sayıda çalışma olmasına karşın, sınırlı sayıda olmakla birlikte olabildiğince ikinci bakış (second look) artroskopisi ve histolojik inceleme ile kıkırdak rejenerasyonunun değerlendirildiği çalışmaların sonuçları sunulmaya çalışılmıştır.

\section{TEK BAŞINA PROKSIMAL TIBIAL OSTEOTOMI SONRASI KIIKIRDAK REJENERASYONU}

Dizilim bozukluğu olan hastalarda osteotomi ile dizilimin düzeltilmesi amaçlanmaktadır. Hastanın yaşı, vücut kitle indeksi, aktivite düzeyi, beklentileri, kıkırdaktaki sorunun büyüklüğü, derinliği, karşılıklı yüzeylerin (femoral ve tibial) etkilenip etkilenmemesi, patellofemoral eklemin durumu gibi etkenler değerlendirilerek osteotomiye ek işlemlerin planlanması yapılabilir. Teorik olarak sadece osteotomi ile dizilim düzeltildiğinde de kıkırdağın yenilenmesi beklenmektedir.

Parker ve ark. açık kama proksimal tibia osteotomisi ile varus dizilimini düzelttikleri 10 hastada ameliyattan 6 ay, 1 yll ve 2 yıl sonra dGEMRIC (delayed gadoliniumenhanced magnetic resonance imaging of cartilage) yöntemi ile radyolojik olarak kıkırdak yenilenmesini değerlendirmişlerdir. 6. aydan sonra 8 hastada (\%80) glikozaminoglikan içeriğini gösteren T1 (Gd) değerlerinin artmaya başladığı görülmüş ve bu bulgu kıkırdakta yenilenme işareti olarak değerlendirilmiştir. ${ }^{[7]}$ Proksimal tibial osteotomi sonrası 6. ayda dGEMRIC yöntemi radyolojik değerlendirme yapılan başka bir çalışmada ise T1 (Gd) değerlerinde anlamlı düzelme görülmediği, tibia kıkırdak yüzeyinde femur kıkırdak yüzeyine göre biraz daha düzelme görüldüğü bildirilmiştir. ${ }^{\left[{ }^{[3}\right.}$

Osteotomi sonrası kıkırdak rejenerasyonunun değerlendirildiği Kanamiya ve ark.'nın çalışmasında 47 hastanın 58 dizine lateral kapalı kama osteotomisi yapılmış ve ameliyattan 18 ay sonra klinik ve artroskopik olarak sonuçlar değerlendirilmiştir. Değerlendirmede kıkırdak bulguları için bir evreleme yapmışlardır. Bu evrelemeye göre; hiç yenilenme olmaması evre 1, dağınık beyaz adacıklar şeklinde fibrokıkırdak oluşumu evre 2, fibröz kıkırdakla kısmi örtünme evre 3, fibröz kıkırdakla tam örtünme evre 4 olarak tanımlanmıştır. Ortalama 18 ay sonra yapılan ikinci bakış artroskopisinde dizlerin \%55'inde hasarlı bölgenin kısmi veya tam kat kıkırdakla örtüldüğünü (evre 3 ve 4), \%34'ünde dağınık yapıda fibrokıkırdak oluştuğu (evre 2) ve sadece $\% 11$ 'inde hiç iyileşme görülmediğini (evre 1) bildirmişlerdir. ${ }^{[2]}$ Wakabayashi ve ark.'nın ortalama yaşları 64 olan ve lateral kapalı kama osteotomisi yapılan 73 hastaya bir yıl sonra uyguladıkları ikinci bakış artroskopisi ve histolojik değerlendirmelerinde kıkırdak kaybı çok olsa bile osteotominin kıkırdak rejenerasyonunu uyardığı, en azından bozulmayı durdurduğunu bildirmişlerdir. ${ }^{[9]}$ Bu çalışmadan çıkarılan ilginç bir sonuç da ameliyat öncesi daha ileri kıkırdak kaybı olanlarda kıkırdakta sadece fibrilleşme olan hastalara göre femur ve tibial yüzeyde daha fazla iyileşme olduğunun görülmesidir. Histolojik olarak hyalin kıkırdak olmasa da iyileşme görülmüş ve bozulma olmadığı saptanmıştır. Koshino ve ark. lateral kapalı kama osteotomisinden iki yıl sonra ikinci bakış artroskopisi yapılan 115 hastanın 146 dizindeki sonuçları yayınlamışlardır. Dizlerin \%8,9'unda kıkırdak iyileşmesi olmadığı, \%58,9'unda fibrokıkırdakla parsiyel iyileşme olduğu, \%32,2'sinde ise iyileşmiş fibrokıkırdak veya hyalin kıkırdak görüldüğünü bildirmişlerdir. Daha iyi iyileşmenin $5^{\circ}$ 'den fazla anatomik valgus açısı verilebilen dizlerde görüldüğü sonucuna varmışlardır. ${ }^{[3]}$ 
Jung ve ark. medial açık kama osteotomisi yapılan ortalama yaşları 60,2 (41-75) olan 159 hastaya ortalama 2 yıl sonra plak vida çıkarılırken yapılan ikinci bakış artroskopisi bulgularının ve klinik değerlendirmenin yapıldığı bir çalışmanın sonuçlarını yayınlamışlardır. Hastaları ameliyat sonrası alt ekstremite diziliminin $0^{\circ}$ veya altında olan, yani yeterli valgizasyon yapılamayan, $0-6^{\circ}$ valgus ve $6^{\circ}$ den büyük valgus açısı elde edilenler olarak üç gruba ayırmışlardır. Kıkırdağı birinci artroskopide International Cartilage Repair Society (ICRS) evresine göre evreleyerek değerlendirmişler ve ikinci bakış artroskopisinde evre 1-olgunlaşmamış (kıkırdak rejenerasyonu yok veya beyaz saçılmalar şeklinde fibrokıkırdak veya kısmi olarak fibrokıkırdakla örtünmüş) ve evre 2-olgunlaşmış (tam olarak fibrokıkırdakla örtünmüş) olarak ikiye ayırmışlar. 16 (\%10) hastada Diz Cemiyeti Skoru (Knee Society Score) (KSS)'nun 64,6'dan 88,1'e yükseldiği, bu hastaların \%19'unda kıkırdak rejenerasyonunun görülmediği, \%75'inde beyaz saçılmalar şeklinde kısmi ya da tam fibrokıkırdak oluştuğu, \%6'sında olgunlaşmış kıkırdak oluştuğu görülmüştür. 133 hastada ideal düzeltme $\left(1-5^{\circ}\right.$ valgus açısı) sağlanmış, KSS ortalama 68,7'den 93,8'e yükselmiş, \%95'inde kısmi veya tam kıkırdak rejenerasyonu saptanırken \%3'ünde tam olgunlaşma görülmüştür. 10 hastada aşırı düzeltme ( $6^{\circ}$ veya üzerinde valgus açısı) yapılmış, KSS ortalama $72,8^{\prime}$ den 81,9 puana yükselmiş, \%90'ında kısmi veya tam kıkırdak rejenerasyonu, \%10'unda tam olgunlaşma görülmüştür. ${ }^{[10]}$

Bu çalışmalar, dizde osteotomi ile dizilimin düzeltilmesinin ve kompartman üzerindeki basıncın yeterince azaltılmasının, ek işlemler olmaksızın kıkırdak rejenerasyonuna zemin hazırladığını, hatta bazı çalışmalarda tam örtünmeye varan iyileşme olduğunu göstermektedir.

\section{OSTEOTOMI ILE BIRLIKTE ARTROSKOPIK DEBRIDMAN VE SUBKONDRAL UYARI IÇEREN IŞLEMLER SONRASI KIKIRDAK REJENERASYONU}

Diz çevresinde dizilim düzeltici bir osteotomi ameliyatında artroskopik olarak eklem içinin değerlendirilmesi genellikle cerrahinin başında uygulanır. Böylece menisküs ve bağ lezyonları gibi eklem içi diğer patolojilerin değerlendirilmesi ve tedavisi, karşı kompartman ve patellofemoral eklem kıkırdağının değerlendirilmesi mümkündür. Ayrıca etkilenen kompartmandaki kıkırdağın durumuna göre ek işlemler de uygulanabilir. Instabil kıkırdak yüzeylerin debridmanı ve düzeltilmesini içeren abrazyon artroplastisi, subkondral kemiğe mikrokırık veya subkondral drilleme işlemlerinin uygulanması en sık yapılan cerrahi işlemlerdendir.
$\mathrm{Bu}$ işlemlerin amacı osteotomi ile kıkırdak üzerine gelen yük ve basıncın azaltılmasıyla birlikte kıkırdak lezyonunun olduğu alanda fibrokıkırdak oluşumunu uyarmaktır.

Akizuki ve ark. tek başına proksimal tibial osteotomi yaptıkları hastalarla osteotomiye ek olarak artroskopik abrazyon artroplastisi yaptıkları hastalarda bir yıl sonraki ikinci bakış artroskopisinde daha düzgün yüzeye sahip kıkırdak rejenerasyonu olduğunu bildirmişlerdir. ${ }^{11]}$

Schuster ve ark. ortalama yaşları 50,4 olan 85 hastanın 91 dizine yapılan artroskopik abrazyon artroplastisi ve mikrokırık işlemi ile birlikte uygulanmış medial açık kama osteotomisinin sonuçlarını yayınlamışlardır. 5 yıllık sağkalımın \%95,2 olduğu ve IKDC (International Knee Documentation Committe) skorlarında 45,1'den 67,2'ye yükselme olduğunu bildirmişlerdir. Osteotomiden ortalama 18 ay sonra yapılan ikinci bakış artroskopisinde ise femoral kıkırdakta \%48,1 iyi ve \%39 mükemmel, tibial tarafta \%50 iyi ve \%25 mükemmel kıkırdak rejenerasyonu kaydetmişlerdir. ${ }^{[1]}$

Jung ve ark. 30 dizde medial açık kama osteotomisine ek olarak uyguladıkları subkondral drillemenin etkisini sadece osteotomi yaptıkları 31 diz ile karşılaştırmışlar ve subkondral drilleme yapılan hastalarda fibrokıkırdakla daha iyi örtünme olduğunu ancak KSS skorlarında istatistiksel olarak anlamlı derecede fark olmadığını bildirmişlerdir. ${ }^{[12]}$

Shon ve ark. hem tibia hem de femurda kıkırdak kaybı ile karakterize "öpüşen (kissing) lezyon"u olan (ortalama yaşları 57,4) 21 hasta (grup 1) ile, sadece femurda kıkırdak kaybı olan (ortalama yaşları $55,5) 22$ hastanın (grup 2) yüksek tibial osteotomi sonrası klinik ve radyolojik sonuçları ile ikinci bakış artroskopik değerlendirmelerini karşılaştırmışlardır. Her iki grupta da hastalara artroskopik debridman ve mikrokırık uygulaması sonrası medial açık kama yüksek tibial osteotomi uygulanmıştır. Ortalama bir yıl sonra klinik skorlarda her iki grupta da istatistiksel olarak anlamlı artış olmuş, Lysholm diz skoru, VAS (Visual Analog Score - Vizüel Ağrı Sokuru) ve HSS (Hospital for Special Surgery Diz Skoru) sadece femurda kıkırdak lezyonu olan grupta daha iyi bulunmuş, diğer skorlar arasında anlamlı fark bulunmamıştır. Hastalara ortalama bir yıl sonra plak-vida çıkarılması sırasında yapılan ikinci bakış artroskopisinde hasarlı alanın genişliğinde \%50'den fazlasında Outerbridge evrelemesine göre bir evre düzelme olanlar tam rejenerasyon, genişliğin \%50'den azında bir evre düzelme olanlar kısmi kıkırdak rejenerasyonu olarak tanımlanmış. Buna göre grup 1'deki 
hastaların \%62'sinde tam, \%38'inde kısmi kıkırdak rejenerasyonu saptanırken, grup 2'deki hastaların \%86'sında tam, \%14'ünde kısmi kıkırdak rejenerasyonu saptanmış. İki grup arasında istatistiksel olarak anlamlı fark bulunmamıştır. ${ }^{[13]}$

Bu çalışmalar yüksek tibial osteotomi ameliyatında uygulanan artroskopik mikrokırık veya subkondral drillemenin kıkırdak rejenerasyonunu uyardığı ve sonuçları olumlu etkilediğini, femur ve tibiada karşılıklı kıkırdak yüzeylerinin de etkilendiği "kissing lezyonlar"da bile bu yöntemle iyi kıkırdak oluşumunun mümkün olduğunu savunmaktadırlar.

\section{OSTEOTOMI ILE BIRLIKTE MOZAIKPLASTI UYGULAMASI}

Mozaikplasti kıkırdak defektlerinde kullanılan ve kemik-kemik iyileşmesi nedeniyle avantajlı sayılabilen bir yöntemdir. Solheim ve ark. ameliyat sırasında ortalama yaşları 36 (16-58) olan medial femoral kondilde $5 \mathrm{~cm}^{2}$ 'nin altında kıkırdak hasarı olan 102 hastanın 52'sine mikrokırık, 50'sine mozaikplasti uygulamışlar ve ortalama 16 (14-18) yıllık uzun dönem sonuçlarını yayınlamışlardır. Ameliyat sonrası 10 yıla kadar mozaikplasti uygulanan hastalarda mikrokırık uygulanan hastalara göre klinik skorların istatistiksel olarak anlamlı ölçüde daha iyi olduğu, 15 yılda ise anlamlı fark olmadığı sonucuna ulaşmışlardır. ${ }^{[14]}$ Aynı yazarlar, randomize kontrollü çalışmalarında 18-50 yaş arasındaki hastaların medial femoral kondildeki 2-5 $\mathrm{cm}^{2}$ 'lik kıkırdak defektlerinde uygulanan mozaikplastinin 15-17. yılda mikrokırık uygulanan hastalara göre daha iyi sonuç verdiği bulgularını yayınlamışlardır. ${ }^{[15]}$

Minzlaff ve ark. ortalama yaşları 38 olan 86 hastaya lateral kapalı kama $(\% 58,1)$ ve medial açık kama $(\% 41,9)$ osteotomisi ile birlikte mozaikplasti uygulamışlar ve ameliyattan 8,5 yıl sonraki takiplerinde ortalama Lysholm skorlarının 40'dan 73'e yükseldiğini, VAS değerlerinin 7,5'dan 2,7 puana düştüğünü ve greft sağkalımının 5. yılda \%95,2, 7. yılda \%93,2 ve 8,5. yılda $\% 90,1$ olduğunu bildirmişlerdir. ${ }^{[16]}$

Matsushita ve ark. varus deformitesi ile birlikte medial femoral kondilde osteonekroz olan 46 yaşında bir hastaya medial açık kama osteotomisi ve mozaikplasti uygulamışlar ve 2 yıl sonra yaptıkları ikinci bakış artroskopisinde defektin rejenere olmuş kıkırdakla tamamen kaplandığını gözlemişlerdir. ${ }^{[17]}$

Osteotomi ile birlikte mozaikplasti uygulamasının özellikle ikinci bakış artroskopisi ile değerlendirilmesi literatürde çok yer bulmamıştır ve bu kombine işlemin objektif etkilerinin değerlendirilebilmesi için yeni çalışmalara gereksinim olduğu gözlenmektedir. ${ }^{[5]}$

\section{OSTEOTOMI ILE BIRLIKTE BIYOLOJIK TEDAVILERIN UYGULANMASI}

Henüz uzun dönem ve yeterli sayıda karşılaştırmalı çalışmalarla kanıt düzeyi yüksek bulgular olmasa da mezenkimal kök hücre uygulamalarının bazı çalışmalarda ağrının giderilmesi üzerine olumlu etkileri olduğu bildirilmiştir. ${ }^{[18-21]}$

Koh ve ark. randomize, prospektif karşılaştırmalı çaIışmalarında proksimal tibial osteotomi yapılan 60 yaş altı ve radyolojik olarak Kelgren Lawrence evrelemesine göre evre III veya daha düşük hastaları iki gruba ayırmışlar ve ortalama yaşları 54,2 olan 21 hastaya osteotomi ile birlikte trombositten zengin plazma (TZP), ortalama yaşları 52,3 olan 20 hastaya osteotomi ile birlikte TZP ve mezenkimal kök hücre enjeksiyonu uygulamışlardır. Hastalara abrazyon veya mikrokırık gibi ek işlem uygulamamışlar, artroskopik olarak medial kompartmanı değerlendirmişler ve randomize seçim yaparak birinci gruba TZP, ikinci gruba karın bölgesinden bir gün önce alınan ciltaltı yağ dokusundan stromal vasküler fraksiyon (SVF) yöntemi ile mezenkimal kök hücre elde ederek osteotomi sonrası diz eklemi içine TZP ile birlikte mezenkimal kök hücre enjeksiyonu yapmışlardır. Hastaların tümüne 14-24 ay sonra plak-vida çıkarılması sırasında ikinci bakış artroskopisi yapmışlar ve Kanamiya ve ark.'nın tariflediği evrelemeye göre medial kompartmandaki kıkırdak bulgularını kaydetmişlerdir. Klinik skorların kök hücre ve TZP yapılan grupta sadece TZP yapılanlara göre daha iyi olduğu saptanmıştır. İkinci bakış artroskopisinde, mezenkimal kök hücre-TZP kombinasyonu uygulanan hastalarda Kanamiya evrelemesine göre \%4,8 evre 1, \%42,9 evre 2, \%38,1 evre 3, \%14,3 evre 4 kıkırdak oluşumu saptanmıştır. Sadece TZP uygulanan hastalarda ise $\% 47,8$ evre 1, \%47,8 evre 2 ve $\% 4,3$ evre 3 kıkırdak oluşumu saptanmış, evre 4 yani tam kıkırdak örtünmesi hiçbirinde görülememiştir. ${ }^{[22]} \mathrm{Bu}$ çalışma mezenkimal kök hücre uygulamasının kıkırdak oluşumu üzerinde istatistiksel olarak anlamlı derecede olumlu etkisi olduğunu vurgulamaktadır. Benzer şekilde Wakitani ve ark.'nın çalışmasında da 12 hastaya kubbe tipi proksimal tibial osteotomi ile birlikte kemik iliği kökenli kültüre edilmiş otolog mezenkimal kök hücre uygulamasının tek başına osteotomiye göre klinik olarak daha iyi sonuç verdiği ve güvenle uygulanabileceği rapor edilmiştir. ${ }^{[23]}$

Saw ve ark. medial açık kama proksimal tibial osteotomisi yaptıkları kemik-kemiğe temas halinde karşılıklı tam kat kıkırdak kaybına sahip ortalama yaşları 52,9 olan 8 hastaya eş zamanlı olarak artroskopik subkondral drilleme uygulamışlar ve ameliyattan bir hafta sonra başlayarak beş hafta haftada bir kez, daha sonra 6., 12 . ve 18. aylarda birer kez eklem içi periferik kan kökenli kök hücre enjeksiyonu uygulamışlardır. Osteotomiden 
ortalama 25,9 ay sonra plak-vida çıkarılması sırasında yapılan ikinci bakış artroskopilerde kıkırdak biyopsileri alınarak International Cartilage Research Society (ICRS)-II histolojik kıkırdak değerlendirme skoru ile değerlendirmişlerdir. ICRS-II skorları ile normal kıkırdağa \%95 benzeyen düzgün yüzeyli rejenere kıkırdak oluştuğunu rapor etmişlerdir. ${ }^{[24]}$

Wong ve ark. 28 hastada sadece medial açık kama osteotomisi ve 28 hastada ostetomi ile birlikte kemik iliği kökenli, kültüre edilmiş mezenkimal kök hücre enjeksiyonu yaptıkları randomize prospektif kontrollü klinik çalışmalarını yayınlamışlardır. Kök hücre enjeksiyonu yapılan grupta yapılmayan gruba göre IKDC, Lysholm ve Tegner skorlarında iyileşme yönünde istatistiksel olarak anlamlı fark bulunmuştur. Cerrahiden bir yıl sonra yapılan MRG (Manyetik Rezonans Görüntüleme)'lerinde kök hücre enjeksiyonu yapılan hastaların \%32'sinde kondral lezyonda tam örtünme, \%36'sında kısmi (\%50'den fazla) örtünme görülürken sadece osteotomi yapılan grupta tam örtünme hiç görülmemiş, kısmi örtünme ise hastaların \%14'ünde görülebilmiştir. ${ }^{[25]}$

Otolog kondrosit implantasyonu (OKi) ile birlikte osteotomi uygulanmasının da kıkırdak yenilenmesini uyaran bir etkiye sahip olduğu düşünülmektedir. Ferruzzi ve ark. medial açık kama osteotomisi yaptıkları 56 hastayı üç gruba ayırmışlar, 20 hastaya sadece osteotomi, 18 hastaya osteotomiye ek olarak otolog kondrosit implantasyonu, 18 hastaya osteotomiye ek olarak mikrokırık uygulamışlardır. Klinik skorlar ve radyografik olarak 11 yıldan fazla takip süresiyle değerlendirdiklerinde OKi uygulanan grubun mikrokırık uygulanan gruba göre klinik skorlarda daha iyi olduğu, radyografik olarak osteoartrit derecesinde ilerlemenin de OKi uygulananlarda daha az görüldüğü, ancak osteotomiyle birlikte OKi uygulanan grubun sadece osteotomi uygulanan gruba benzer sonuçlar aldığı belirtilmiştir. ${ }^{[26]}$

Bode ve ark. ise varus derecesi 5'in altında olan sadece OKi implantasyonu uyguladıkları 24 hastayla medial açık kama osteotomisi ile birlikte OKi uyguladıkları 19 hastanın sonuçlarını karşılaştırmışlardır. Klinik skorlarla değerlendirilen işlevsel sonuçlar ve revizyon cerrahisi gerekliliği değerlendirildiğinde osteotomi ile birlikte OKI uygulamasının daha iyi sonuçlar verdiğini, osteotomi ve OKI yapılanlarda 2 hastada, sadece OKI yapılanlarda 10 hastada revizyon gerektiğini bildirmişlerdir. Yazarlar genel eğilim olan medial femoral kondilde kıkırdak kaybı olan $5^{\circ}$ 'nin üzerindeki varus deformitelerinde osteotomi yapılması önerisinin $5^{\circ}$ 'nin altındaki deformitelerde de geçerli olduğunu, biyolojik tedavilerin sonuçlarını iyileştirdiği yargısına varmışlardır. ${ }^{[27]}$
Otolog kondrosit implantasyonu defekt alanının 5 $\mathrm{cm}^{2}$ 'nin altında olduğu, 30 yaşından genç hastalarda ve dizilim düzeltici osteotomi ile birlikte uygulandığında daha iyi sonuç vermektedir. ${ }^{[28]}$

Kim ve ark. medial kondral lezyonu olan ve beraberinde yüksek tibial osteotomi yapılan 42-68 yaşları arasında hastalarda randomize olarak iki grup oluşturmuş ve 36 hastaya yağ dokusu kökenli mezenkimal kök hücre fibrin yapıştırıcı ile, 34 hastaya mezenkimal kök hücre ile birlikte taze kadavra kostasından elde edilen allojenik kıkırdak sentetik matriks içerisinde yerleştirmişlerdir. Ortalama bir yıl sonra ikinci bakış artroskopisi yapılan ve 3 yıl klinik skorlar ve radyolojik olarak takip edilen hastalarda allojenik kıkırdak uygulanan grupta sonuçların daha iyi olduğu belirlenmiştir. ${ }^{[29]}$

\section{ÇIKARIMLAR VE SONUÇ}

Diz ekleminde dizilim bozukluğu ile birlikte kıkırdak kaybı özellikle genç aktif hastalarda ağrı ve günlük aktivitelerde belirgin bozulmalara neden olmaktadır. Dizilim düzeltici osteotomiler semptomların giderilmesi ve ağrısız aktif yaşama dönüş için güvenli ve etkili cerrahilerdir. ${ }^{[5]}$

Diz eklemindeki dizilim bozukluğunun giderilmesi kıkırdak kaybının ileri evrelere ulaşmadan düzeltilmesi osteoartritin ilerlemesini önlemek bakımından önemlidir. Osteotomi ile yük, sağlam olan karşı kompartmana aktarılarak etkilenen bölgedeki anormal kuvvetler azaltılır. Güçlü tespit materyalleriyle erken yük verme, erken hareket açıklığının kazanılması iyileşmeye ve normal aktivitelere daha çabuk dönülmesine katkıda bulunur ve erken hareket kıkırdak yenilenmesini olumlu yönde etkiler. ${ }^{[30]}$

Tek başına osteotomi ile dizilimin düzeltilmesinin etkilenen kompartmandaki basıncın azalması ile kıkırdak yenilenmesi üzerine olumlu etki yaptığı çalışmalarda gösterilmiştir. ${ }^{[31]}$ Kıkırdak yenilenmesi için kullanılan yöntemlerle (abrazyon, mikrokırık, mozaikplasti, otolog kondrosit transplantasyonu, kök hücre enjeksiyonu) birlikte uygulandığında osteotominin kıkırdak yenilenmesi üzerindeki etkisinin arttığı sonucu literatürdeki çalışmalar ışığında rahatlıkla söylenebilir. ${ }^{[32]}$

Farklı bir açıdan bakıldığında ise, kıkırdak restorasyonu için uygulanması planlanan bir yöntemin başarılı olabilmesi için öncelikle dizin stabilitesinin ve diziliminin normal olması gerektiği unutulmamalıdır. Yani kıkırdak yenileyici bir cerrahi yapmadan önce, eğer dizilim bozuksa dizilim düzeltici osteotominin kıkırdak yenilenmesinin ön şartı olduğu bilinmelidir. Dolayısıyla kıkırdak yenilenmesi üzerine hem osteotominin hem de kıkırdak yenileyici işlemlerin birlikte olumlu etkisi olduğu tartışılmazdır. Ancak kıkırdak restorasyonu için 
hangi yöntemin daha iyi olduğu henüz bilinmemektedir. Bunun için daha geniş kapsamlı, benzer hasta özelliklerine sahip ve tüm yöntemlerin değerlendirildiği gruplarla, uzun dönem takip edilerek klinik, radyolojik, ikinci bakış artroskopisi ve histolojik değerlendirme içeren yayınlara gereksinim vardır.

\section{KAYNAKLAR}

1. Schuster $P$, Schulz $M$, Mayer $M$, Schlumberger $M$, Immendoerfer M, Richter J. Open-Wedge High Tibial Osteotomy and Combined Abrasion/Microfracture in Severe Medial Osteoarthritis and Varus Malalignment:5-Year Results and Arthroscopic Findings After 2 Years. Arthroscopy 2015;31(7):1279-88. Crossref

2. Kanamiya T, Naito M, Hara M, Yoshimura I. The influences of biomechanical factors on cartilage regeneration after high tibial osteotomy for knees with medial compartment osteoarthritis: Clinical and arthroscopic observations. Arthroscopy 2002;18(7):725-9. Crossref

3. Koshino $T$, Wada $S$, Ara $Y$, Saito $T$. Regeneration of degenerated articular cartilage after high tibial valgus osteotomy for medial compartmental osteoarthritis of the knee. Knee 2003;10(3):229-36. Crossref

4. Amendola A, Bonasia DE. Results of high tibial osteotomy: Review of the literature. Int Orthop 2010;34(2):155-60. Crossref

5. Thambiah MD, Tan MKL, Hui JHP. Role of high tibial osteotomy in cartilage regeneration - Is correction of malalignment mandatory for success? Indian J Orthop 2017;51(5):588-99. Crossref

6. Brinkman JM, Lobenhoffer P, Agneskirchner JD, Staubli AE, Wymenga $A B$, van Heerwaarden RJ. Osteotomies around the knee: Patient selection, stability of fixation and bone healing in high tibial osteotomies. J Bone Joint Surg Br 2008;90B(12):1548-57. Crossref

7. Parker DA, Beatty KT, Giuffre B, Scholes CJ, Coolican MR. Articular cartilage changes in patients with osteoarthritis after osteotomy. Am J Sports Med 2011;39(5):1039-45. Crossref

8. Rutgers M, Bartels LW, Tsuchida AI, Castelein RM, Dhert WJ, Vincken KL, van Heer waarden RJ, Saris DB. dGEMRIC as a tool for measuring changes in cartilage quality following high tibial osteotomy: a feasibility study. Osteoarthritis Cartilage 2012;20(10):1134-41. Crossref

9. Wakabayashi S, Akizuki S, Takizawa T, Yasukawa Y. A comparison of the healing potential of fibrillated cartilage versus eburnated bone in osteoarthritic knees after high tibial osteotomy: An arthroscopic study with 1-year followup. Arthroscopy 2002;18(3):272-8. Crossref

10. Jung WH, Takeuchi R, Chun CW, Lee JS, Ha JH, Kim JH, Jeong JH. Second look arthroscopic assestment of cartilage regeneration after medial opening-wedge high tibial osteotomy. Arthroscopy 2014;30(1):72-9. Crossref

11. Akizuki S, Yasukawa $Y$, Takizawa $T$. Does arthroscopic abrasion arthroplasty promote cartilage regeneration in osteoarthritic knees with eburnation? A prospective study of high tibial osteotomy with abrasion arthroplasty versus high tibial osteotomy alone. Arthroscopy 1997;13(1):9-17. Crossref

12. Jung $\mathrm{WH}$, Takeuchi $\mathrm{R}$, Chun $\mathrm{CW}$, Lee JS, Jeong JH. Comparison of results of medial opening wedge high tibial osteotomy with and without subchondral drilling. Arhroscopy 2015;31(4):673-9. Crossref
13. Shon OJ, Park SJ, Shim BJ, Lee DY. Comparative study of clinical and radiographic outcomes of high tibial osteotomy in patients with kissing lesions and non-kissing lesions. Knee Surg Relat Res 2017;29(4):288-94. Crossref

14. Solheim E, Hegna J, Inderhaug E. Long term clinical follow up of microfracture versus mosaicplasty in articular cartilage defects in medial femoral condyle. Knee 2017;24(6):1402-7. Crossref

15. Solheim E, Hegna J, Strand T, Harlem T, Inderhaug E. Randomized Study of Long-term (15-17 years) Outcome After Microfracture Versus Mosaicplasty in Knee Articular Cartilage Defects. Am J Sports Med 2018;46(4):826-31. Crossref

16. Minzlaff $P$, Feucht MJ, Saier $T$, Schuster $T$, Braun $S$, Hinterwimmer S. Osteochondral autologous transfer combined with valgus high tibial osteotomy: long term results and survivorship analysis. Am J Sports Med 2013;41(10):2325-32. Crossref

17. Matsushita T, Watanabe S, Araki D, Matsumoto T, Takayama K, Kurosaka M, Kuroda R. High tibial osteotomy combined with cancellous bone graft and osteochondral autograft transplantation in a patient with massive osteochondral defect in the medial femoral condyle. J Orthop Surg 2017;25(1):2309499016685016. Crossref

18. Koh YG, Jo SB, Kwon OR, Suh DS, Lee SW, Park SH, Choi YJ. Mesenchymal stem cell injections improve symptoms of knee osteoarthritis. Arthroscopy 2013;29(4):748-55. Crossref

19. Mcllwraith CW, Frisbie DD, Rodkey WG, Kisiday JD, Werpy NM, Kawcak CE, Steadman JR. Evaluation of intraarticular mesenchymal stem cells to augment healing of microfractured chondral defects. Arthroscopy 2011;27(11):1552-61. Crossref

20. Pas HI, Winters M, Haisma HJ, Koenis MJ, Tol JL, Moen MH. Stem cell injections in knee osteoarthritis: a systematic review of the literature. Br J Sports Med 2017;51(15):1125-33. Crossref

21. Xing D, Kwong J, Yang Z, Hou Y, Zhang W, Ma B, Lin J. Intraarticular injection of mesenchymal stem cells in treating knee osteoarthritis: a systematic review of animal studies. Osteoarthritis Cartilage 2018;26(4):445-61. Crossref

22. Koh YG, Kwon OR, Kim YS, Choi YJ. Comparative Outcomes of Open-Wedge High Tibial Osteotomy With PlateletRich Plasma Alone or in Combination With Mesenchymal Stem Cell Treatment: A Prospective Study. Arthroscopy 2014;30(11):1453-60. Crossref

23. Wakitani S, Imoto K, Yamamoto T, Saito M, Murata N, Yoneda M. Human autologous culture expanded bone marrow mesenchymal cell transplantation for repair of cartilage defects in osteoarthritic knees. Osteoarthritis Cartilage 2002;10(3):199-206. Crossref

24. Saw KY, Anz A, Jee CS, Ng RC, Mohtarrudin N, Ragavanaidu $\mathrm{K}$. High tibial osteotomy in combination with chondrogenesis after stem cell therapy: A histologic report of 8 cases. Arthroscopy 2015;31(10):1909-20. Crossref

25. Wong KL, Lee KB, Tai BC, Law P, Lee EH, Hui JH. Injectable cultured bone marrow derived mesenchymal stem cells in varus knees with cartilage defects undergoing high tibial osteotomy: A prospective, randomized controlled clinical trial with 2 years' followup. Arthroscopy 2013;29(12):20208. Crossref

26. Ferruzzi A, Buda R, Cavallo M, Timoncini A, Natali S, Giannini S. Cartilage repair procedures associated with high tibial osteotomy in varus knees: Clinical results at 11 years' followup. Knee 2014;21(2):445-50. Crossref 
27. Bode G, Schmal H, Pestka JM, Ogon P, Südkamp NP, Niemeyer P. A non-randomized controlled clinical trial on autologous chondrocyte implantation $(\mathrm{ACl})$ in cartilage defects of the medial femoral condyle with or without high tibial osteotomy in patients with varus deformity of less than $5^{\circ}$. Arch Orthop Trauma Surg 2013;133(1):43-9. Crossref

28. Minas T, Von Keudell A, Bryant T, Gomoll AH. A minimum 10year outcome study of autologous chondrocyte implantation. Clin Orthop Relat Res 2014;472(1):41-51. Crossref

29. Kim YS, Chung PK, Suh DS, Heo DB, Tak DH, Koh YG. Implantation of mesenchymal stem cells in combination with allogenic cartilage improves cartilage regeneration and clinical outcomes in patients with concomitant high tibial osteotomy. Knee Surg Sports Traumatol Arthrosc 2019. Crossref
30. Esenkaya i, Poyanlı O. Frontal dizilim bozuklukları, osteotomiler ve yeni kıkırdak oluşumu. In: Bozkurt $M$, Tandoğan RN, Elmalı N, Aktekin $\mathrm{CN}$, editörler. Kıkırdak. İstanbul: TUSYAD Eğitici Kitap Serisi. İstanbul Tıp Kitabevleri Yayınları; 2016. ss.147-61.

31. Choi JR, Yong KW, Choi JY. Effects of mechanical loading on human mesenchymal stem cells for cartilage tissue engineering. J Cell Physiol 2018;233(3):1913-28. Crossref

32. Kahlenberg CA, Nwachukwu BU, Hamid KS, Steinhaus ME, Williams RJ. Analysis of Outcomes for High Tibial Osteotomies Performed with Cartilage Restoration Techniques. Arthroscopy 2017;33(2):486-92. Crossref 